\author{
(online) $=$ ISSN $2285-3642$ \\ ISSN-L = 2285 - 3642 \\ Journal of Economic Development, Environment and People \\ Volume 2, Issue 4, 2013 \\ URL: http://jedep.spiruharet.ro \\ e-mail: office jedep@spiruharet.ro
}

\title{
Environmental management and its application in the Slovak Republic
}

\author{
Ing. Mariana Dubravská, PhD. ${ }^{1}$ \\ University of Prešov, Slovakia
}

\begin{abstract}
The Paper aims at implementation of environmental management in the condition of Slovak Republic. Systems of the environmental management represent the mean of practical realization of environmental requirements, competitiveness indicator, tool of the sustainable development support and acknowledgement of good environmental behavior by regulation of the business activities impacts. Standard scientific research methods included synthesis, analysis and comparative method.
\end{abstract}

Keywords: environmental management, EMAS, EMS, Slovak Republic

JEL Codes: Q56, Q59, 013

\section{Introduction}

Ongoing globalization process has different meanings. Globalization is a process connecting people, places, institutions and events in the world. Globalization is a growing tendency directing to the achievement of the unified network of the cash flow, human resources, products and ideas. It is worldwide distribution and interaction of the economical, political and cultural processes.

The term globalization is generally used to describe an increasing internationalization of markets for goods and services, the means of production, financial systems, competition, corporations, technology and industries. Amongst other things this gives rise to increased mobility of capital, faster propagation of technological innovations and an increasing interdependency and uniformity of national markets.

Environmental criticism is based on the finite resources and environment. It mentions several facts. The most important are regional disparities as a result of globalization. Increasing interest in an environmental issue has disclosed deficiencies and faults in practicability of the environment issue. It has reflected by nature of the making decision process and approaches of the practical solution of the environmental problems. These have been considered as a regional but nowadays we focus on them as on global ones.

The most serious global environmental problems are:

- global warming

- weakening of the stratospheric ozone layer

\footnotetext{
${ }^{1}$ Corresponding author - Tel.: +421 (0)51 77759 24, E-mail address: mariana.dubravska@unipo.sk
} 


\author{
(online) $=$ ISSN $2285-3642$ \\ ISSN-L = 2285 - 3642 \\ Journal of Economic Development, Environment and People \\ Volume 2, Issue 4, 2013 \\ URL: $\underline{\text { http://jedep.spiruharet.ro }}$ \\ e-mail: office jedep@spiruharet.ro
}

- acidic atmospheric deposition

- biodiversity threats

- soil degradation

- water contamination

- waste production.

Based on the rapidly worsening situation in the environment the relationship among the man and the environment has changed during the last decades. Many documents have been ratified. They have resulted from the praxis and they have become the basis for management concept of systemic policy and environmental management as well as many national and international activities.

The interest in the environmental performance of organizations is continually increasing. Taking a proactive approach to environmental challenges is now the hallmark of successful organizations.

\title{
2. Environmental Management
}

Management represents the file of the voluntary environmental policy tools that enables the implementation of the systematic approach to the solution of the environment protection problems by the application of the environmental innovations of the firms.

The most important tools are:

- environmenatl management systems acoording to the standard ISO 14001 (EMS) or acording to the EU Eco-Management and Audit Scheme (EMAS)

- system of the environmental management of the supply chain

- environmental accounting

- environmental reporting

- environmental audit

- life cycle assessment (LCA)

- materials flow statement

- environmenatl communication

- "green Office“

\subsection{EMAS}

The EU Eco-Management and Audit Scheme (EMAS) is a management instrument developed by the European Commission for companies and other organizations to evaluate, report, and improve their environmental performance. EMAS is open to every type of organization eager to improve its environmental performance. It spans all economic and service sectors and is applicable worldwide.

Currently, more than 4,500 organizations and approximately 8,150 sites are EMAS registered worldwide; among them are many multinational enterprises, smaller companies as well as public authorities. 


\author{
(online) $=$ ISSN $2285-3642$ \\ ISSN-L = $2285-3642$ \\ Journal of Economic Development, Environment and People \\ Volume 2, Issue 4, 2013 \\ URL: $\underline{\text { http://jedep.spiruharet.ro }}$ \\ e-mail: office jedep@spiruharet.ro
}

EMAS is a voluntary tool available for any kind of organization aiming to:

- Improve its environmental and financial performance;

- Communicate its environmental achievements to stakeholders and society in general.

- EMAS' distinctive key elements are performance, credibility and transparency:

PERFORMANCE: EMAS is a voluntary environmental management instrument based on a harmonised scheme throughout the EU. Its objective is to improve the environmental performance of organisations by having them commit to both evaluating and reducing their environmental impact, and continuously improving their environmental performance.

CREDIBILITY: The external and independent nature of the EMAS registration process (Competent Bodies, Accreditation/Licensing Bodies and environmental verifiers under the control of the EU Member States) ensures the credibility and reliability of the scheme. This includes both the actions taken by an organisation to continuously improve its environmental performance, and the organisation's disclosure of information to the public through the environmental statement.

TRANSPARENCY: Providing publicly available information on an organisation's environmental performance is an important aspect of the scheme's objective. It is achieved externally through the environmental statement and within the organisation through the active involvement of employees in the implementation of the scheme. The EMAS logo, which can be displayed on (inter alia) letterheads, adverts for products, activities, and services, is an attractive visual tool which demonstrates an organisation's commitment to improving its environmental performance and indicates the reliability of the information provided.

EMAS Institutional provision in the Slovak Republic:

- Ministry of Environment of the Slovak Republic - coordinator of the section of EcoManagement and Audit in the context of the revised Regulation (EC) No 1221/2009 of the European Parliament

- Slovak National Accreditation Service - national accreditation organization performing an accreditation of the environmental verifiers and supervision of their activities

- Slovak Environmental Agency - professional organization of the Ministry of the Environment of the Slovak Republic (MoE SR) with nationwide scope of powers, which focuses on the environment protection and landscape planning in accordance with principles of sustainable development 
(online) = ISSN $2285-3642$

ISSN-L = 2285 - 3642

Journal of Economic Development, Environment and People

Volume 2, Issue 4, 2013

URL: http://jedep.spiruharet.ro

e-mail: office jedep@spiruharet.ro

Table 1: List of Slovak companies registered in EMAS Register

\begin{tabular}{|l|l|l|l|}
\hline \multicolumn{1}{|c|}{$\begin{array}{c}\text { Registration } \\
\text { number }\end{array}$} & \multicolumn{1}{|c|}{ Organization } & Date of registration & \multicolumn{1}{|c|}{$\begin{array}{c}\text { Validity of the } \\
\text { environmental statement }\end{array}$} \\
\hline SK - 000008 & Gold-Pack spol. s r.o., Beluša & 23.07 .2013 & 17.05 .2016 \\
\hline DE-158-00016 & $\begin{array}{l}\text { Schaeffler Group INA Kysuce, } \\
\text { a.s., Kysucké Nové Mesto } \\
\text { INA SKALICA, spol. S r.o., } \\
\text { Skalica }\end{array}$ & 14.03 .2013 & 31.07 .2015 \\
\hline SK -0006 & SEWA, a.S., Bratislava & 01.11 .2008 & 13.05 .2015 \\
\hline
\end{tabular}

Source: Slovak environmental agency, 2013

The List of organizations established in the Slovak Republic is registered in EMAS Register - an online database hosted by the European Commission which lists all EMAS registered organizations and sites. Slovak companies listed in EMAS Register are mentioned in Table 1.

\subsection{EMS}

It is voluntary tool of the environmental management in the organization, established to manage its important environmental aspects and to achieve conformity with legal requirements. It involves organizational structure, planning, liability, processes, procedures and sources for the preparation, application, review and maintenance of the organizational environmental policy. It enables then achievement and systematic management of the organizational environmental behaviour. It is generally used management principle that links environment protection approaches with the total organizational management aimed to achieve environmental and business goals.

EMS is usable for any type of organization in the industry, agriculture, services, health service, trade, financial sector or in the government.

EMS Benefits can be found in these fields:

Economical benefits

- Energy saving

- Water saving

- Waste minimization

- Economical use of raw materials

- Recycling

- Costs overview and monitoring

- Minimization of the environmental fees and fines for pollution

- Reduction of the cost of insurance 


\author{
(online) $=$ ISSN $2285-3642$ \\ ISSN-L = 2285 - 3642 \\ Journal of Economic Development, Environment and People \\ Volume 2, Issue 4, 2013 \\ URL: http://jedep.spiruharet.ro \\ e-mail: office jedep@spiruharet.ro
}

\title{
Benefits for the organization management
}

- Tool for the data acquisition needed for planning

- Means of the objective assessment of the business environmental performance and efficiency of the adopted measures

- Minimization of the environmental emergencies risks

- Organizational ethics increasingr

- Environmental problems and risks overvies and monitoring

Relations with employers

- Reduction of the negative impacts on the employers

- Increased involvement of the employers into the environmental management process

- Environmental knowledge formation

Public relations

- Valuable tool of the communication with interested groups

- Organizational image improving

- Good relations with the public and local government

Benefits for business activity and marketing

- Gaining certification as required in Standard ISO 140001 or EMAS represents for businesses competitive advantage in the world market even domestically

- Market opportunities increasing

- Image improving

EMS Institutional provision in the Slovak Republic:

Coordinator of the EMS implementation in the Slovak Republic through the basic and standardization provision is Ministry of Environmnet of the Slovak Republic.

Slovak National Accreditation Service was determined as a national accreditation organ of the Slovak Republic. Number of certificates from the year 1990-2012 is shown in a Fig. 1. 

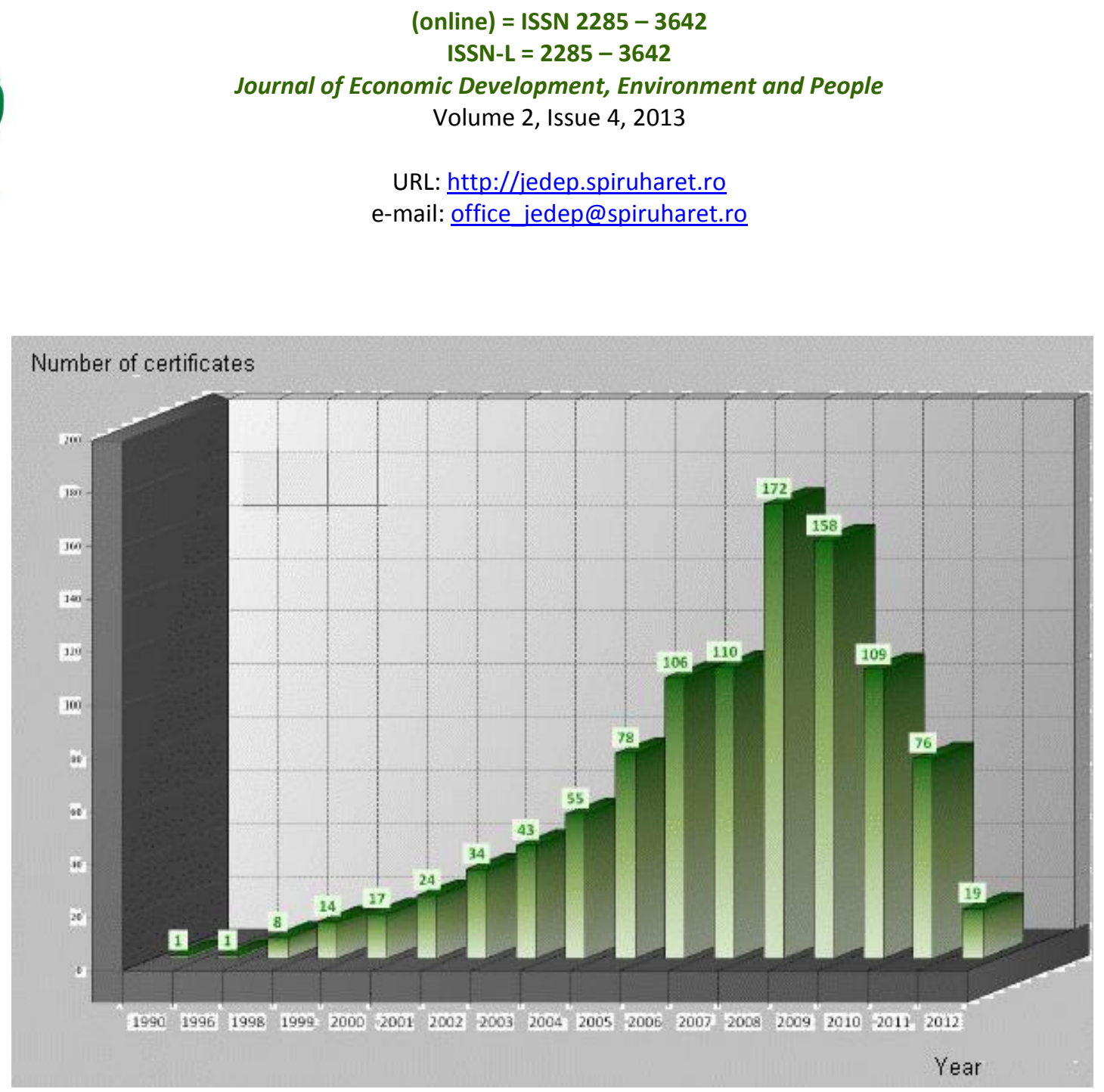

Fig. 1: EMS Certification according to Standard 14001- increase of the certificated organizations Source: Slovak environmental agency, 2013

\subsection{EMAS vs. EMS}

Documents resulting from the common principle -to initiate the active approach of the businesses towards the improving of the relationship with the environment. They differ by fact that some system components are recommended by one document and required by another. Both systems are similar and they differ formally. They are used concurrently in one organization only exceptionally. The most important differences in extents and requirements between EMS and EMAS are appointed in Table 1 below. 


$$
\begin{gathered}
\text { (online) }=\text { ISSN } 2285-3642 \\
\text { ISSN-L = 2285 - } 3642
\end{gathered}
$$

Journal of Economic Development, Environment and People

Volume 2, Issue 4, 2013

URL: http://jedep.spiruharet.ro

e-mail: office jedep@spiruharet.ro

\begin{tabular}{|c|c|c|}
\hline Extent & EMS & EMAS \\
\hline Teritorial operation & worldwide & European Union \\
\hline Management system & contained & contained \\
\hline Validity for types of activities & all types & $\begin{array}{c}\text { mainly manufacturing industrial } \\
\text { activities }\end{array}$ \\
\hline Input analysis & recommended & required \\
\hline Impact register & recommended & required \\
\hline Environmental statement & not required & required \\
\hline Competent authority & Not required & Required \\
\hline Business subject registration & Not required & Required \\
\hline Audit cycle & undetermined & the longest period of three years \\
\hline End process management & certification & $\begin{array}{c}\text { environmental statement verification, } \\
\text { locality registration }\end{array}$ \\
\hline
\end{tabular}

Table 1: The most important differences in extents and requirements of EMS and EMAS

Source: own processing according to Environmental magazine and Slovak University of Technology, 2007

\section{Conclusion}

We cannot expect significant changes in the Slovak Republic in the field of "green" procurement that would be conditional on EMS introduction at authority and products and services suppliers

Implementation of the environmental managerial systems in the conditions of the Slovak republic is often conditional by relations with organizations and business partners. Businesses that act as subcontractors of the foreign companies are very often bound by duty to implement corresponding quality system as well as environmental managerial system. These businesses are even effective by environmental goals achievement as their relations with partners are conditioned by ensuring the environmental managerial systems quality and by observing corresponding standard of these systems that directly influence the quality of their production and services.

The importance of the EMS implementation however consists of the fact that it enables to create framework rules for the effective organization management as a whole or its individual parts. The other advantage of the EMS implementation in conjunction with other voluntary tools is marketing asset of these systems. 


\author{
(online) $=$ ISSN $2285-3642$ \\ ISSN-L = 2285 - 3642 \\ Journal of Economic Development, Environment and People \\ Volume 2, Issue 4, 2013 \\ URL: http://jedep.spiruharet.ro \\ e-mail: office jedep@spiruharet.ro
}

\title{
4. References
}

[1] ENVIRONMENTAL MAGAZINE. [online, quoted to 20.10.2013]. Available at:

http://www.enviromagazin.sk/enviromc1 3/systemy14.html

[2] EUROPEAN COMISSION. [online, quoted to 20.10.2013]. Available at:

http://ec.europa.eu/environment/emas/about/index en.htm

[3] CENTRE OF SOCIETY, ECONOMY AND ECOLOGY. [online, quoted to 20.10.2013]. Available at:

http://www.ekologika.sk/environmentalne-manazerstvo.html

[4] OECD: Manual on Statistics of International Trade in Services, Eurostat, IMF, OECD, UN, UNCTAD, WTO, 2002 Annex II, Glossary

[5] PROJECT GO ECO! ENVIRONMENTAL SERVICES FOR SMEs. [online, quoted to 20.10.2013]. Available at: http://www.go-eco.sk/userfiles/file/10\%20Environmentalne\%20manazerske\%20systemy.pdf

[6] SAKÁL, P.: Environmental business strategy. Trnava: Slovak University of Technology, 2007, 82p., [online, quoted to 20.10.2013]. Available at:

http://www.scss.sk/smpmcd/files/semestralne projekty1/environmentana\%20strategia\%20podniku/Environme ntalna\%20strategia\%20podniku.pdf

[7] SHORT, J.R.: Global Dimension. London: FOCI publ., 2001, 189p., ISBN 1-86189-102-4J.

[8] SLOVAK ENVIRONMENTAL AGENCY. [online, quoted to 20.10.2013]. Available at:

http://www.sazp.sk/public/index/go.php?id=1723 